\title{
From individual sustainability orientations to collective sustainability innovation and sustainable entrepreneurial ecosystems
}

\section{Author(s)}

DiVito, Lori; Ingen-Housz, Zita

DOI

10.1007\%2Fs11187-019-00254-6

Publication date

2021

Document Version

Author accepted manuscript (AAM)

Published in

Small Business Economics, An Entrepreneurship Journal

Link to publication

\section{Citation for published version (APA):}

DiVito, L., \& Ingen-Housz, Z. (2021). From individual sustainability orientations to collective sustainability innovation and sustainable entrepreneurial ecosystems. Small Business Economics, An Entrepreneurship Journal, 56, 1057-1072.

https://doi.org/10.1007\%2Fs11187-019-00254-6 


\title{
From individual sustainability orientations to collective sustainability innovation and sustainable entrepreneurial ecosystems
}

\author{
Lori DiVito* \\ Amsterdam University of Applied Sciences \\ Amsterdam School of International Business \\ Amsterdam, The Netherlands \\ Email: 1.e.d.divito@hva.nl \\ Phone: +31621157353 \\ Zita Ingen-Housz \\ Amsterdam University of Applied Sciences \\ Center for Applied Research on Economics and Management \\ Amsterdam, The Netherlands
}

*Corresponding author

Accepted for publication in Small Business Economics

February 2019

\begin{abstract}
Sustainability and economic growth - the integration and balance of social, environmental and economic needs - is a salient concern for sustainable development and social well-being. By focusing on a sustainable innovation project, we explore how entrepreneurial ecosystems become sustainable entrepreneurial ecosystems and investigate the interactions of entrepreneurial actors. We conducted an inductive, single-case study of a specific collaborative innovation project in the denim industry specialized in a specific geographic location. From our data we show that the presence of four conditional aspects foster sustainable entrepreneurial ecosystems. These include: sustainability orientation of actors, recognition of sustainable opportunities and resource mobilization, collaborative innovation of sustainability opportunities and markets for sustainable products. We make two observations that contribute to the literature. First, we see that in a sustainable entrepreneurial ecosystem, entrepreneurial experimentation is a highly interdependent and interactive process. Secondly, we see that recognition of sustainable opportunities is distributed among different actors in the ecosystem. Our findings also have implications for practitioners and policy makers.
\end{abstract}

Keywords: entrepreneurial ecosystems, sustainable entrepreneurial ecosystems, sustainable entrepreneurship, innovation systems, apparel

JEL Classification: L26, L67 


\section{Acknowledgments}

We express our gratitude to the Special Issue Editors and reviewers for their insightful and constructive suggestions that led to substantial improvements of this paper. We also extend our gratitude to the entrepreneurs and firms that participated in this study and generously shared their time and experience with us. 


\section{Introduction}

Empirically we see more and more entrepreneurs embracing entrepreneurial action to create social or environmental value as well as economic value. Scholars refer to entrepreneurship that aims to balance the triple bottom line of social, ecological and economic development as sustainable entrepreneurship (Elkington, 1994; Shepherd \& Patzelt, 2011). We draw on the definition provided by Shepherd and Patzelt (2011: 142) that sustainable entrepreneurship is "focused on the preservation of nature, life support and community in the pursuit of perceived opportunities ... for economic and non-economic gain ...”. In efforts to balance these different dimensions of entrepreneurial activities, sustainable entrepreneurs face complex tradeoffs; for instance decisions that benefit the environment may have unintended consequences for social or economic well-being (Hahn et al, 2014; Hahn et al, 2015). In turn, sustainable entrepreneurs have to reconcile a persistent dual orientation sustainability orientation and entrepreneurial orientation - from which they aim to do good while pursuing entrepreneurial opportunities (DiVito \& Bohnsack, 2017).

Sustainable entrepreneurship entails entrepreneurial exploration and exploitation activities in underdeveloped, developing or developed markets with highly uncertain outcomes (Bank, Fichter \& Klofsten, 2017; Muñoz \& Cohen, 2018; Shepherd \& Patzelt, 2011). Prior work argues that this kind of uncertain entrepreneurial action flourishes in entrepreneurial ecosystems where the benefits of interaction with ecosystem actors increases access to resources and knowledge, legitimizes entrepreneurial ventures and reduces risk (Kuratko et al, 2017). Yet, we do not know whether entrepreneurial ecosystems, as they are currently theorized in the extant literature, support sustainable entrepreneurship.

We argue that sustainable entrepreneurship differs in significant ways than traditional entrepreneurship. For example, we know that the role of activists or stakeholder groups and the natural environment is more prominent in sustainable entrepreneurial ecosystems, or eco-industrial parks (Cohen, 2006). Additionally, the motivations to engage in entrepreneurship and innovation to resolve sustainability issues or pursue more sustainable opportunities may not be purely profit motivated placing constraints on financial resources (Dorado, 2006; Mair \& Marti, 2006). Also, as the benefits and outcomes of sustainable entrepreneurship may accrue more collectively or focus on common goods, sustainable entrepreneurs may have difficulty capturing value from their innovations (Dean \& McMullen, 2007; York \& Venkataraman, 2010). It follows from this reasoning that sustainable entrepreneurs may require different ecosystems where actors interact and provide support in 
significantly different ways than in traditional entrepreneurial ecosystems (Autio et al, 2018; Neumeyer \& Santos, 2018).

The recent literature on entrepreneurial ecosystems builds on established work on national and regional economic and innovation systems (Nelson, 1993; Edquist,1997; Freeman, 2002), which has shown that resources (e.g. knowledge, finance) are embedded in various actors and institutions and that innovation and entrepreneurship flourishes or fades within them (Zahra \& Nambisan, 2011). National, regional and metropolitan areas develop specialized (technical) knowledge and expertise in industry clusters or ecosystems that function as anchors attracting talent and businesses, driving innovation and economic development (Edquist, 1997; Florida, Gulden \& Mellander, 2008; Nelson, 1993).

Recently scholars have turned their attention to understanding entrepreneurship more holistically, as part of larger ecosystems of interactions between actors, such as institutions, firms and individuals, that engage in innovative and entrepreneurial activity (Audretsch \& Belitski, 2016; Autio et al, 2014). Ecosystems manifest on various levels, such as the national, regional and local levels, and the boundaries are permeable as some resources, such as financing, can travel easily across geographic boundaries and others such as tacit knowledge, do not. Geographic proximity of actors aids the transfer of highly tacit, sticky, locally-embedded knowledge that is not easily accessed or transferred across borders (Gertler, 2003).

We draw on innovation and entrepreneurial ecosystems literature to investigate and illuminate the systemic conditions that aid sustainable entrepreneurship. In doing so, we extend the current theorizing on entrepreneurial ecosystems to include a layer of sustainability. We ask the question: how does an entrepreneurial ecosystem become a sustainable entrepreneurial ecosystem?

To address this question, we conducted an inductive, single-case study of a specific innovation project in an industry specialized in a specific geographic context. Using a collaborative innovation project as the unit of analysis, we studied the interactions of entrepreneurial experimentation of the actors, which is indicative of the strength of innovative activity in an entrepreneurial ecosystem (Audrestch \& Link, 2017). Using data from semi-structured interviews and longitudinal observations over a period of two years and archival documentation, we find the presence of four conditions. These include 1) sustainability orientation of actors, 2) the recognition of sustainable opportunities and resource mobilization, 3) collaborative innovation of sustainability opportunities, and 4) markets for sustainable products. The conditions, which have embedded interactions and interdependencies among various actors in the ecosystem, are reinforcing and support the emergence of a 
sustainable entrepreneurial ecosystem. We contribute to the emerging literature on sustainable entrepreneurial ecosystems by showing that the interdependency of actors is salient and that opportunity recognition is distributed across different actors in the sustainable entrepreneurial ecosystem. We also contribute to the sustainable entrepreneurship literature by providing a more nuanced view of the innovative and entrepreneurial actions of sustainable entrepreneurs.

The paper is structured as follows. In the next section, we present the theoretical background. Following that we explain the research method, the case context and present the findings. In the final sections, we discuss the implications and conclusion.

\section{Theoretical background}

\subsection{Sustainable entrepreneurship}

The sustainable entrepreneurship literature argues that economic entrepreneurial action can contribute to solving complex social and ecological issues and that these types of entrepreneurs act as a catalyst for industrial transformation (Cohen \& Winn, 2007; Hall et al, 2010; Hockerts \& Wüstenhagen, 2010; Muñoz \& Dimov, 2015; Parrish, 2010; Schaltegger \& Hansen, 2013). Sustainable entrepreneurship builds on previous work in social entrepreneurship and ecological (or green) entrepreneurship but it is also distinct from these fields. Ecopreneurs pursue opportunities to resolve highly uncertain ecological problems with ambiguous outcomes, long term horizons and high business uncertainty. Ecopreneurs are most likely to act and innovate when profits can be gained, suggesting that they establish for-profit ventures (Cohen \& Winn, 2007; Dean \& McMullen, 2007; York \& Venkataraman, 2010). Social entrepreneurship may be more mission-driven than profit-driven (Dorado, 2006; Mair \& Marti, 2006) and there is much variance in how social benefits are incorporated in strategic organizational goals (Zahra et al, 2009). For example, the social enterprise may create social wealth with little, or no, economic wealth (e.g. charity, non-profits) whereas others may create social as well as economic wealth (for-profit). Sustainable entrepreneurship, however, takes a more integrated, holistic perspective in pursuing opportunities (Schlange, 2009) and aims to balance tradeoffs more equally between the three dimensions of economic, ecological and social sustainability (DiVito \& Bohnsack, 2017).

Scholars are increasingly studying sustainable entrepreneurship as distinct from traditional entrepreneurship (Belz \& Binder, 2017; Shepherd \& Patzelt, 2011). Sustainable entrepreneurs, inclusive of ecoand social entrepreneurs, are dually oriented towards social responsibility on the one hand and entrepreneurial exploration and exploitation on the other. They have to reconcile conflicting values and logic when making 
decisions and grapple with unique and persistent tradeoffs (De Clercq \& Voronov, 2011; Hahn et al, 2015) when compared to traditional entrepreneurs who do not have this dual orientation. Because sustainable entrepreneurs aim to address pressing societal challenges and improve societal well-being, they have the potential to create disruptive change and transform industry practices (Hall et al, 2010; Hockerts \& Wüstenhagen, 2010). However, scholars criticize this view for overpromising their potential as disruptive change agents and further point out that sustainable entrepreneurs cannot act in isolation (Hall et al, 2010; Schaltegger and Wagner, 2011). As a recent phenomenon, extant literature has only just begun investigating sustainable entrepreneurship and the complicated interaction between sustainable development and innovative, entrepreneurial activity. To understand sustainable entrepreneurship, scholarship needs to explore the pursuit of sustainability opportunities as embedded in entrepreneurial ecosystems, its interaction with various actors and its manifestations at micro, macro and geographic levels (Bischoff \& Volkmann, 2018; Meek, Pacheco \& York, 2010; Simatupang, Schwab \& Lantu, 2015).

\subsection{Sustainability, innovation systems and entrepreneurial ecosystems}

The systems literature more generally - innovation systems, national business systems, entrepreneurial ecosystems - posits that economic actors are not isolated and that the institutional context in which they engage for entrepreneurial, innovative or economic activity matters (Bergek et al, 2008; Whitley, 2000). Scholars have examined national, regional and local systems of economic development and innovation and have shown that different contextual environments shape economic outcomes and innovation processes (Asheim \& Coenen, 2005, Asheim \& Isaksen, 2002; Soskice \& Hall, 2001). Prior work has also shown that the components of systems act in reinforcing ways; in other words, particular constellations of economic and innovation systems will be conducive or restrictive to particular patterns of economic or innovation behavior (Casper, 2007a, 2007b; Casper \& Whitley, 2004) leading to economic and innovation specialization in areas of knowledge, workforce skills and industries.

As has been pointed out more recently by scholars, innovation (eco)systems literature focuses on the dynamics and evolution of actors (e.g. cross fertilization) as an interconnected process and network of public and private actors that preserves ecosystem resilience and survival (Lundvall et al, 2002; Roundy, Brockman \& Bradshaw, 2017). In the innovation systems literature, scholars point out the lack of attention to the actions of the entrepreneur (Alvedalon \& Boschma, 2017). The exception is a study from Bergek and colleagues (2008) which puts forth an analytical framework for innovation systems that includes several key systemic processes, 
one of which is entrepreneurial experimentation. They argue that entrepreneurial experimentation is essential to reduce uncertainty of technological innovation and without this key functional process an innovation system would stagnate. In this regard, entrepreneurial action is a central process in innovation systems.

The growing interest in entrepreneurial ecosystems addresses the gap in the literature to understand entrepreneurial action (new value creation and capture) in complex, multi-level economic systems (Acs et al, 2017; Neck et al, 2004; Simatupang et al, 2015). Entrepreneurial ecosystems emphasize the entrepreneur and his actions based on contextual characteristics and components of the systems (Glaeser et al, 2001; Glaeser et al, 2014; Isenberg, 2010; Neck et al, 2004; Spigel, 2015; Stam, 2014; Stam, 2015; Szerb, Acs \& Autio, 2013; Woolley, 2014). It stands to reason that ambitious entrepreneurship that engages in entrepreneurial experimentation to explore and exploit innovative opportunities (Bergek, Jacobsson, \& Sandén, 2008; Smith \& Raven, 2012; Stam, 2015; Wesseling \& Van der Vooren, 2017) arises from vibrant ecosystems where resources and knowledge flow easily among actors. These two literatures on innovation (eco)systems and entrepreneurial ecosystems have not yet been well linked, with the exceptions of studies from Bergek and colleagues (2008) and from Audretsch and Link (2017), who investigated how the governance of research joint ventures affects the inclusion of actors from the entrepreneurial ecosystem to engage in entrepreneurial experimentation or innovative activity.

We take the position that sustainable entrepreneurs engage in entrepreneurial experimentation to innovate products, business models and institutions and in doing so engage in highly uncertain markets with ambiguous performance outcomes. As such, sustainable entrepreneurs draw on the strengths of innovation and entrepreneurial ecosystems. We consider innovation ecosystems and entrepreneurial ecosystems to be intertwined spatially as they share common components of public and private organizations. We posit, however, that sustainable entrepreneurship requires distinct configurations of institutions and actors in order to thrive in entrepreneurial ecosystems (Bischoff \& Volkmann, 2018).

We posit that sustainability in entrepreneurial ecosystems is unique for a few reasons. First, sustainable entrepreneurs seek solutions to grand societal issues - for example climate change, water preservation or poverty. The time horizon for search, experimentation and implementation is of a long term nature and requires long term inter-firm relations with actors in the entrepreneurial ecosystem. For example, Marsden and Smith (2005), in their study on ecological entrepreneurship in the food industry, claim that specialized regional and local networks form as collective responses to problems of sustainable development. These networked forms of 
ecological entrepreneurship encourage spatial relationships, or 'socio-technological niches', in which individuals and network actors respond entrepreneurially to competitive and global forces. Their study highlights the importance of the interaction between ecological entrepreneurs utilizing natural resources in new and innovative ways and the larger political and social environment.

Secondly, the recognition and exploitation of sustainability opportunities may require different actors those that highlight the issues, those that invent alternative products or materials and those that take entrepreneurial action. Recent work on 'activist entrepreneurship' highlights how actors as individuals or organized groups engage in "disruptive truth-telling" (Dey \& Mason, 2018: 85) to unleash transformative forces and change the collective imagination. They argue that disruptive truth-telling requires reflexivity and knowledge from other entrepreneurial actors (e.g. those that invent new products) to understand the social and political assumptions that activist entrepreneurs target and to experiment with possible alternatives.

Lastly, capturing value from the entrepreneurial action of sustainability opportunities is challenging due to the dispersed collective benefits and spillovers to other actors (Barnett, 2006). This implies that entrepreneurial ecosystems focused on sustainable entrepreneurship may function differently than those focused on traditional entrepreneurship. Additionally, if sustainable entrepreneurs are likely to be change agents who disrupt industry status quo, then it stands to reason that they may engage in institutional entrepreneurship to a greater degree than traditional entrepreneurs. Their entrepreneurial actions within the ecosystem may have a direct effect on the course and evolution of the (sustainable) entrepreneurial ecosystem (Muñoz and Dimov, 2015; Pacheco et al, 2010).

The literature to date has paid scant attention to the role of the sustainable entrepreneur in entrepreneurial ecosystems (Bischoff \& Volkmann, 2018). Our aim in this paper is to address this gap in the entrepreneurial ecosystem and sustainable entrepreneurship literatures. We investigate empirically sustainable entrepreneurial experimentation and uncover the distinctive conditions that support continued sustainable entrepreneurship. In our study, we ask the question how an entrepreneurial ecosystem becomes a sustainable entrepreneurial ecosystem.

\section{Methods}

We use an inductive, single-case study to address our research question. A case study design is appropriate because we aim to explore the becoming of sustainable entrepreneurial ecosystems. An inductive, qualitative approach of an entrepreneurial ecosystem allows us to dive deep into the phenomenon and uncover the 
sustainability conditions that influence activities, behavior and interactions of entrepreneurial actors over time (Langley, 1999) rather than reveal a relationship between variables (Langley et al, 2013).

We use a single-case study design and selected a specialized industry (denim) that has a strong concentration in a specific location (Amsterdam). Prior literature on entrepreneurial ecosystems often uses a case methodology based on parameters of location or industry (Bank et al, 2015; Etzkowitz \& Klofsten, 2005; Spigel, 2015). Following the example of Audretsch and Link (2017), we use a case study of a collaborative innovation project with multiple units of analysis - the project, the actors and the broader ecosystem. A collaborative innovation project highlights activities of high risk and uncertainty that are typically carried out by various actors in entrepreneurial ecosystems where spatial and cognitive proximity support innovative behavior. Using a case study method, we gain deep insights into the actors and the contexts in which they operate in order to extend and build theory (Eisenhardt, 1989; Yin, 2003).

\subsection{Data Collection}

For the last four years the authors have become increasingly involved and embedded in the denim industry in Amsterdam. Our higher education institution provides education and conducts research in the denim industry such that it is an actor in the local denim entrepreneurial ecosystem. From 2016-2018, we conducted a government funded research project that focused on improving the ecological sustainability impact of denim production. From this research project, we gained first-hand experiences and insights from our continued and regular contact with key local and international entrepreneurial actors.

For this paper, we collected data using a variety of sources including semi-structured interviews, direct observation and publicly available documentation (Table 1). Our data collection was guided by protocols developed a priori from literature. We created a case study database so that we could chronologically follow the project and the associated documentation. We gathered data retrospectively about the start of the project and held in-depth interviews with the collaborating firms at two points in time over a six-month period. During the six-month period we visited one of the entrepreneurial actors (Denim City) several times and observed how collaboration took place in physical space.

Insert Table 1 


\subsection{Data analysis}

We transcribed the interviews and coded the transcripts. We created a narrative of the interviews to understand the time and sequence of events as they unfolded. We discussed and verified the narrative account with the respondents. Using these techniques and guided by theory, we devised analytical constructs with which to further analyze the data (Figure 1). We derived inductively from our data first order concepts, second order themes and aggregated explanatory constructs (Gioia et al, 2013). We moved iteratively between theoretical concepts, our data transcripts and analytical constructs using pattern matching and explanation building techniques (Pentland, 1999). Explanation building is often used in conjunction with pattern matching and allowed us to uncover causal links and explain why or how a particular event or outcome occurred. Through this iterative, sense-making process, we moved from our surface observations to more abstract theory development, a reflexive process that allowed us to make a conceptual leap (Klag \& Langley, 2013). Lastly, we shared and discussed the findings of our analysis with our respondents.

Insert Figure 1

\section{The Amsterdam denim industry}

The Amsterdam denim industry is a thriving entrepreneurial ecosystem that has a strong focus on sustainable innovation. Worldwide the denim industry, as a subsector of the fashion or apparel industry, represents a substantial proportion of the annual textile volume produced. As in the larger apparel industry, the denim industry faces grave and specific challenges in terms of social and ecological sustainability. Due to greater scrutiny of denim production by non-governmental organizations (e.g. CleanClothesCampaign) and consumer activist groups (e.g. Fashion Revolution), there is increasing pressure on denim industry actors to address sustainability issues. The reduction of water consumption, hazardous chemicals and textile waste are particularly salient issues for the industry.

\subsection{Actors in the Amsterdam Denim Industry}

Specialized denim design organizations, such as brands and retailers, and denim production organizations, such as denim mills, laundries (cut, sew and finishing factories), chemical manufacturers, equipment manufacturers, consultants, are concentrated geographically. Table 2 provides an overview of these geographic specializations.

Insert Table 2 
In the last decade or so, the presence of denim designers and brands in Amsterdam has been increasing and approximately 30 denim brands have established either their headquarters or design and sales offices in the Amsterdam area. Additionally, international denim mills have established showrooms and have representatives in Amsterdam. Informal and formal networks have developed among peers and have led to new initiatives and ventures, with local young (boutique) brands spinning off and starting up. The mobility of actors allows for knowledge and talent to flow through these informal and formal networks.

As a location, Amsterdam has become a European hub for denim. Since 2014 Amsterdam has hosted Kingpins, a prestigious biannual denim trade fair to source denim fabric and production suppliers, and the associated Transformers seminar that highlights specific sustainability issues and innovations in the denim industry. Amsterdam also annually hosts Denim Days, an event for different stakeholders in the ecosystem with an emphasis on reaching the consumer. The Dutch consumer markets are receptive denim buyers; the informal, direct and egalitarian culture of the Dutch embraces denim as a fashion item. The Dutch consumer owns on average five pairs of jeans and contributes to the rich denim ecosystem.

The Dutch local and national government policies also support the development and growth of the denim ecosystem. The municipality of Amsterdam provides access to physical spaces and buildings and there are two Amsterdam-based educational institutions that offer unique denim specializations, contributing to the local talent pool. Additionally there is a range of (national and international) support organizations and nongovernmental organizations (NGOs) located in Amsterdam focused on the industry and sustainability issues. Figure 2 maps the actors in the Amsterdam denim entrepreneurial ecosystem.

\section{Insert Figure 2}

The focus on sustainability in the Amsterdam denim industry dates back to the early 2000s when the first Amsterdam sustainable denim brand started. However, sustainability became more central to the entrepreneurial ecosystem with the founding of House of Denim in 2009. House of Denim's mission is to make the denim industry cleaner, dryer and smarter. It is an internationally recognized innovation platform located in Amsterdam and aims to lead denim industry transformation in sustainability.

There are two main pillars in the House of Denim concept: Denim City and the Jeans School. Denim City, a physical space, offers lab space, store space and educational space for industry workshops and networking. Denim City is a central support organization at the heart of the denim industry, bringing together 
denim actors to innovate collaboratively. Although locally embedded within the Amsterdam denim industry, the focus and reach is global in scale, as evidenced in its expansion to Los Angeles and Japan.

\subsection{Our empirical case}

We purposefully selected Denim City as a vehicle to study how actors interact in an entrepreneurial ecosystem and to understand in more depth how an entrepreneurial ecosystem becomes a sustainable entrepreneurial ecosystem. Denim City engages in various ecosystem activities; it provides training, store space and a platform for local and international collaboration. As a central ecosystem actor, Denim City represents a revelatory case such that the researchers were able to observe over time a phenomenon that is not easily accessible and analyze aspects of sustainable entrepreneurial ecosystems. Furthermore, our case selection has methodological fit with nascent theory building (Edmondson \& McManus, 2007) and sheds light on a phenomenon that is little understood.

We focus specifically on a collaborative innovation project that Denim City initiated on post-consumer recycled denim (henceforth, PCRD). Denim City's aim with the PCRD project was to collectively increase the volume of PCRD produced to lower the cost of production and aid a broader adoption in the industry. The sustainability benefits of PCRD related to taking the first steps towards a circular production process, in which discarded jeans are collected, shredded and rewoven into new fabric, reducing textile waste and water consumption. There was also the added benefit of educating Jean School students in the process of producing and designing with PCRD.

The PCRD project had two distinct phases. The goal of the first phase was to use $20 \%$ recycled cotton in denim fabric production. It reached $18 \%$ and produced a collection in the spring of 2015 . The second phase aimed to further reduce water consumption by adding the alternative material hemp into the fabric blend. The goal of the second phase was to increase the recycled cotton content to $25 \%$, use $25 \%$ hemp fiber and $50 \%$ organically grown virgin cotton. It achieved a result of $21 \%, 7 \%$ and $72 \%$ respectively and produced a collection for spring 2016.

Using the PCRD project as an indicator of the behavior of an entrepreneurial ecosystem, we focus our analysis in the next section on the interactions of the four main actors of the PCRD project - the intermediary organization (Denim City), an Amsterdam-based denim brand (Denim Brand), an Amsterdam-based social entrepreneur (Textile Collector) and a European denim mill (Denim Mill) - highlighting the conditions that 
favor innovative and experimental collaboration for sustainability improvements and facilitate a transition to a sustainable entrepreneurial ecosystem.

\section{Analysis of findings}

From our analysis of the PCRD project, we identified the presence of four interrelated conditions of sustainability in an entrepreneurial ecosystem. We argue that these conditions underpin the processual formation and persistence of a sustainable entrepreneurial ecosystem. The conditions are: 1) sustainability orientation of actors, 2) recognition of sustainable opportunities and resource mobilization, 3) collaborative innovation for sustainability and 4) markets for sustainable products. The relation between the conditions and between the actors in the entrepreneurial ecosystem are illustrated in Figure 3. Below we outline the four conditions and discuss the implications. Table 3 provides selected quotations for each condition.

\section{Insert Figure 3}

\subsection{Sustainability orientation of entrepreneurs}

One of the conditional aspects of a sustainable entrepreneurial ecosystem is the presence of actors that have a sustainability orientation embedded in their organizations. These are the sustainable entrepreneurs who found or work for organizations that are born sustainable or have sustainability values in their DNA. From our case, we observed a concentration in Amsterdam of denim brands as well as support organizations with strong sustainability orientations, which in turn attracted actors beyond Amsterdam that had ambitions to incorporate sustainability practices into their business models.

For the PCRD project, there were several partners that had established sustainability orientations. Denim City and Denim Brand were founded on principles of sustainability and these were embedded and integrated into their business models. The sustainability leadership of these firms was a main reason for Denim Mill to participate in the PCRD project. Denim Mill, located in Spain, referred to Amsterdam as a hotspot for sustainable denim. As an organization that aimed to transition to more sustainable production practices, Denim Mill was eager to collaborate with Denim City.

We observed from our data that not only is sustainability orientation of actors a necessary condition for the recognition and pursuit of sustainability opportunities, it is also widely dispersed among various actors in the entrepreneurial ecosystem. For the emergence of a sustainable entrepreneurial ecosystem, additional actors with sustainability orientations, other than entrepreneurs and firms, contributed to the prevalence of sustainability in 
the Amsterdam denim entrepreneurial ecosystem. The sustainable orientations of especially non-governmental organizations were significant. These kinds of organizations keep a watch on industry practices, bring to light a host of unsustainable social or environmental practices, and place pressure on the industry to act. Although these actors as activists highlight sustainability problems or issues in the industry and bring a sense of urgency to them, they do not craft a response to them. It is the sustainable entrepreneur who recognizes sustainability opportunities and mobilizes resources to collaboratively address sustainability issues.

\subsection{Recognition of sustainability opportunities and resource mobilization}

In the PCRD project, the actors in the denim ecosystem were keenly attuned to opportunities that afforded sustainability benefits. Denim City, as the main actor and initiator of the project, aimed to increase the volume of PCRD produced, which would create economies of scale, reduce the costs per meter and increase broader adoption by the industry. It was driven from private interest for Denim City to produce denim for the Jeans School but also for the collective interests of the ecosystem and larger society to reduce water consumption in denim production.

Locational and cognitive proximity were key aspects of the actors' recognition of the sustainable opportunity and the ability of the initiator, Denim City, to assemble resources. Denim City found partners quickly due to their similar sustainability orientations, which provided alignment of interests in goal setting. In assembling partners for resources, Denim City secured a government subsidy as well as access to corporate financing and raw materials (collected used jeans) from the Textile Collector. For technical expertise, Denim City drew on experience and resources from Denim Mill for the spinning and weaving of PCRD fabric. Denim Brand contributed design expertise and created two product collections from PCRD fabric to market to consumers. The complementary resources and skills from the various partners created an interdependence among the actors and reinforced the shared risks and benefits that is evident in ecosystems. Although Denim City acted as a catalyst for the PCRD project, recognizing the opportunity of scaling post-consumer recycled denim, the other engaged actors - Textile Collector, Denim Mill and Denim Brand - also recognized the opportunity benefits for their own individual organizations.

\subsection{Collaborative innovation of sustainability opportunities}

To realize benefits from recognized opportunities, actors need to engage in exploration and exploitation activities. In entrepreneurial ecosystems, collaborative innovation by actors (for example in the form of joint ventures or research projects) is indicative of the strength of the ties among actors and the ability to combine 
knowledge and resources to explore or exploit opportunities of high risk and uncertainty. Sustainability in the denim entrepreneurial ecosystem in Amsterdam rooted because the collaborative effort of actors focused on opportunities or problems that addressed a value proposition that improved sustainability in value chain production, providing (a promise of) collective or social benefits, as well as economic gains to individual organizations.

For the PCRD project, there was much iteration and experimentation in the process, or in getting to a 'formula'. Denim Mill ran several production runs to test various strengths of recycled yarns and various blends (recycled yarns, hemp and virgin cotton) until Denim Brand was satisfied with the end result. All of the PCRD partners learned from the knowledge exchange and iterative experimentation. This kind of experimental collaborative activity is not unique for innovation ecosystems. However, innovation for sustainability carries additional risks as it may require capital expenditure for technological equipment, the use of materials where the outcome is less known and the development of uncertain markets.

\subsection{Markets for sustainable products}

Entrepreneurial action focuses on value creation and capture and the ability to appropriate rents from sustainable products is another important condition of sustainable entrepreneurial ecosystems. The founder of Denim City explained the vicious demand-supply cycle of the market: denim mills were not producing fabrics with PCRD because brands were not asking for it, and brands were not asking for it because consumers weren't buying it. A primary aim of the PCRD project was to stimulate demand for PCRD in product and factor markets. In this way, the PCRD project was an initial start in getting mills to produce denim fabric with some recycled content and in getting brands to make collections and sell the story to the consumer.

Although the Amsterdam denim entrepreneurial ecosystem has both consumers that value sustainability in denim and denim brands that are producing sustainable products, two factors prevented the actors from capturing value from the PCRD project. First, there were limitations in technology to produce fabrics with recycled cotton that met consumers' needs in terms of comfort (fit) and durability. Second, due to the experimentation in the process, and particularly with the second phase of PCRD which included hemp fibers in the blend, the price per meter of fabric increased to a level that eroded any economic benefit. However, with continued technological development, these limiting factors that suppressed demand in product and factors markets may fade. 


\section{Discussion of implications}

Our study explores the question how an entrepreneurial ecosystem becomes a sustainable entrepreneurial ecosystem. This is a difficult question to address given that, in the extant literature, theorizing of entrepreneurial ecosystems is still largely debated (Alvadelena \& Boschma, 2017). Nonetheless, there is a general agreement that entrepreneurial ecosystems place entrepreneurial action, the creation and capture of value, at the heart of the ecosystem (Autio et al, 2014). From this perspective, we analyzed an entrepreneurial ecosystem using a collaborative innovation project within a specialized industry that is spatially concentrated in a geographic location. We identified and explained the presence of four conditions that enabled a sustainable entrepreneurial ecosystem to materialize. Table 4 summarizes these conditions.

\section{Insert Table 4}

We make two main observations from our findings that are important contributions to the nascent literature on sustainable entrepreneurial ecosystems. The first observation of sustainable entrepreneurial ecosystems is that interdependency of actors is salient, where actors share risks but also benefits of pursuing opportunities that require substantial entrepreneurial experimentation (Audretsch \& Keilbach, 2007). Sharing risks and benefits of ambitious entrepreneurship binds actors together and makes the ecosystem stronger and more resilient (Roundy et al, 2017). As prior work has shown in regional innovation systems, knowledge sharing and transfer through networks, collaboration and labor mobility have positive effects on the growth and development of an ecosystem (Autio et al, 2014; Saxenian, 1994; Almeida and Kogut, 1999). We see in our data that knowledge sharing was central to the PCRD project partners' desire to collaborate together. In a geographically confined area as the Amsterdam metropolitan area, everyone knows everyone. Tacit knowledge travels easily across firm boundaries with the mobility of labor. This resonates with the established literature on Silicon Valley and the continued innovative activity of this regional innovation system (Autio et al, 2014; Saxenian, 1994).

The innovation (eco)systems literature provides much insight about how to manage this interdependency through transaction cost perspectives, e.g. governance structures and internalization strategies (Watkins et al, 2015; Wesseling \& Van der Vooren, 2017) and resource based view perspectives, e.g. complementary resources, dynamic capabilities. The literature on entrepreneurial ecosystems, and by extension sustainable entrepreneurial ecosystems, has much to gain from using insights from innovation systems, especially for the experimentation or exploration phase of the entrepreneurial process (Bergek et al, 2008). Our 
study is a first step in this line of inquiry as it uncovers conditions that are favorable for the exploration of sustainable opportunities or innovation.

Our second observation of sustainable entrepreneurial ecosystems is that the local proximity and presence of support or non-profit organizations facilitates the recognition of sustainable opportunities. In this way, opportunity recognition and creation requires the interaction of different actors in the entrepreneurial ecosystem, suggesting that actors also share the cognitive processes of seeing opportunities as well as the experimental processes of developing opportunities into innovative solutions (Kuratko et al, 2017). The entrepreneurship literature has long debated entrepreneurial agency in the discovery or creation of opportunities (Alvarez \& Barney, 2007). Our study shows not only the agentic nature of opportunity recognition but also that opportunities are recognized and created by the interaction and coming together of various actors in the entrepreneurial ecosystem. In a sustainable entrepreneurial ecosystem, this suggests the presence of expert organizations on sustainability issues that exert pressure to change, whether they are consumer activists, regulators or solution providers for the industry and shows the importance of activist entrepreneurship in the recognition, exploration and exploitation of sustainability opportunities (Dey \& Mason, 2018). This implies that opportunities are networked, socially constructed occurrences that require coordinated efforts in entrepreneurial ecosystems and resonates with the view of 'ecosystems-as-structure' (Adner, 2017) which places the joint definition and realization of a value proposition at the heart of an ecosystem.

Our study helps to shed light on the conceptualization of sustainable entrepreneurial ecosystems and contributes to the literature in this field. Furthermore, our study contributes to the emerging literature on sustainable entrepreneurship. As an empirical case study of a sustainable innovation project, we provide evidence that sustainable entrepreneurs are highly ambitious and innovative entrepreneurs (York \& Venkataraman, 2010). We show that sustainable innovation is not an isolated activity and that indeed sustainable entrepreneurs engage in institutional entrepreneurship (Pacheco et al, 2010). However, in our data, we see more nuance among the sustainable actors in a sustainable entrepreneurial ecosystem. Entrepreneurs of for-profit firms, even if they have a sustainable orientation, faced complicated tradeoffs in balancing the economic, social and ecological dimensions of sustainable innovation. We saw that the sustainable institutional entrepreneurs were situated in non-profit organizations where changing the institutional status quo was a deeprooted motivation. We also observed that sustainable entrepreneurs are resource constrained which limits their capacity to bring about transformational industrial change. In this way, our findings concur with scholars of 
sustainable entrepreneurship who claim that systemic sustainability change needs to come from, or in combination with, incumbent firms (Schaltegger \& Hansen, 2013).

\subsection{Implications for practitioners and policy makers}

Our study has practical implications for actors within the ecosystem including entrepreneurs, managers, investors, educators and policy makers. Actors who initiate collaborative action within the ecosystem need to mobilize the advantages of having a strong sustainability orientation. Policy makers should develop incentives and schemes that support the sustainability orientation of actors in entrepreneurial ecosystems, such as attracting support organizations to establish local offices, encouraging knowledge transfer for sustainability-oriented innovative activity and stimulating the creation of new sustainability-oriented firms and products. Additionally policy makers should be aware of intrinsic local and regional sustainability-oriented conditional strengths and avoid duplicating other successful ecosystems like Silicon Valley without any local translation. Incentives for collaboration and innovation to improve sustainability impact, such as tax schemes, could support the specific efforts of actors in sustainable entrepreneurial ecosystems.

\subsection{Limitations}

Our study is not without limitations. As a qualitative case study based on a specific regional and local area and on a specific sub sector (denim) of the apparel industry, the generalization of our findings may be limited. Despite this limitation, our findings about what makes an entrepreneurial ecosystem become a sustainable entrepreneurial ecosystem may apply to industries (such as the food industry or the chemical industry) that also face increasing pressure from sustainability activists and require transformative innovation from ecosystem actors. As a relatively new concept, there is much more research needed to fully understand the mechanisms and performance of sustainable entrepreneurial ecosystems. For example, how do we determine the performance of sustainable entrepreneurial ecosystems? It can be argued that the dependent variable often used in studies on entrepreneurial ecosystems, new firm creation or growth, may not capture the performance outcomes of sustainable entrepreneurial ecosystems. Additionally, more research could be done about the individual action of specific actors and how that interacts with the broader sustainable entrepreneurial ecosystem. Or, whether specific types of actors in sustainable entrepreneurial ecosystems are more likely to engage in institutional entrepreneurship. Lastly, research on the boundary conditions, geographically and organizationally, of sustainable entrepreneurial ecosystems could lead to more insight on the growth and success of sustainable entrepreneurial ecosystems. 


\section{Conclusion}

Sustainable entrepreneurship is becoming increasingly important to study because various industries face dire sustainability concerns and business as usual is putting increasing strain on our planet's resources and risking the well-being of future generations. However, sustainable entrepreneurship requires complicated tradeoffs and coordinated action among entrepreneurial actors. We show that actors in an entrepreneurial ecosystem pursue sustainable innovation and entrepreneurship when four conditions of sustainability are present. These conditions are: sustainability orientation of actors, recognition of sustainable opportunities and resource mobilization, collaborative innovation of sustainability opportunities and markets for sustainable products. The favorable presence of these conditions allow sustainable entrepreneurs to interact and engage in entrepreneurial experimentation that focuses on sustainable solutions, products and innovations. 


\section{References}

Alvarez, S. A., \& Barney, J. B. (2007). Discovery and creation: Alternative theories of entrepreneurial action. Strategic Entrepreneurship Journal, 1(1-2), 11-26.

Acs, Z. J., Autio, E., \& Szerb, L. (2014). National systems of entrepreneurship: Measurement issues and policy implications. Research Policy, 43(3), 476-494.

Acs, Z. J., Stam, E., Audretsch, D. B., \& O’Connor, A. (2017). The lineages of the entrepreneurial ecosystem approach. Small Business Economics, 1-10.

Adner, R. (2017). Ecosystem as structure: an actionable construct for strategy. Journal of Management, 43(1), 39-58.

Almeida, P., \& Kogut, B. (1999). Localization of knowledge and the mobility of engineers in regional networks. Management Science, 45(7), 905-917.

Alvedalen, J., \& Boschma, R. (2017). A critical review of entrepreneurial ecosystems research: towards a future research agenda. European Planning Studies, 25(6), 887-903

Asheim, B. T., \& Coenen, L. (2005). Knowledge bases and regional innovation systems: Comparing Nordic clusters. Research Policy, 34(8), 1173-1190.

Asheim, B. T., \& Isaksen, A. (2002). Regional innovation systems: the integration of local 'sticky' and global 'ubiquitous' knowledge. The Journal of Technology Transfer, 27(1), 77-86.

Audretsch, D.B. \& Belitski, M. J. (2017). Entrepreneurial ecosystems in cities: establishing the framework conditions. The Journal of Technology Transfer, 42(5), 1030-1051.

Audretsch, D. B., \& Keilbach, M. (2007). The theory of knowledge spillover entrepreneurship. Journal of Management Studies, 44(7), 1242-1254.

Audretsch, D. B., \& Link, A. N. (2017). Embracing an entrepreneurial ecosystem: an analysis of the governance of research joint ventures. Small Business Economics, 1-8.

Autio, E., Nambisan, S., Thomas, L. D., \& Wright, M. (2018). Digital affordances, spatial affordances, and the genesis of entrepreneurial ecosystems. Strategic Entrepreneurship Journal, 12(1), 72-95.

Autio, E., Kenney, M., Mustar, P., Siegel, D., \& Wright, M. (2014). Entrepreneurial innovation: The importance of context. Research Policy, 43(7), 1097-1108.

Bank, N., Fichter, K., \& Klofsten, M. (2017). Sustainability-profiled incubators and securing the inflow of tenants-The case of Green Garage Berlin. Journal of Cleaner Production, 157, 76-83.

Barnett, M. L. (2006). Finding a working balance between competitive and communal strategies. Journal of Management Studies, 43(8), 1753-1773.

Belz, F. M., \& Binder, J. K. (2017). Sustainable entrepreneurship: A convergent process model. Business Strategy and the Environment, 26(1), 1-17.

Bergek, A., Jacobsson, S., \& Sandén, B. A. (2008). 'Legitimation'and 'development of positive externalities': two key processes in the formation phase of technological innovation systems. Technology Analysis \& Strategic Management, 20(5), 575-592.

Bergek, A., Jacobsson, S., Carlsson, B., Lindmark, S., \& Rickne, A. (2008). Analyzing the functional dynamics of technological innovation systems: A scheme of analysis. Research Policy, 37, 407-429.

Bischoff, K. \& Volkmann, C.K. (2018). Stakeholder support for sustainable entrepreneurship - a framework of sustainable entrepreneurial ecosystems. International Journal of Entrepreneurial Venturing, 10(2), 172-201.

Casper, S. (2007a). Creating Silicon Valley in Europe: Public policy towards new technology industries. Oxford University Press. 
Casper, S. (2007b). How do technology clusters emerge and become sustainable?: social network formation and inter-firm mobility within the San Diego biotechnology cluster. Research Policy, 36(4), 438-455.

Casper, S., \& Whitley, R. (2004). Managing competences in entrepreneurial technology firms: a comparative institutional analysis of Germany, Sweden and the UK. Research Policy, 33(1), 89-106.

Cohen, B. (2006). Sustainable valley entrepreneurial ecosystems. Business Strategy and the Environment, 15(1), $1-14$.

Cohen, B., \& Winn, M. (2007). Market imperfections, opportunity and sustainable entrepreneurship. Journal of Business Venturing, 22(1), 29-49.

Dean, T. J., \& McMullen, J. S. (2007). Toward a theory of sustainable entrepreneurship: Reducing environmental degradation through entrepreneurial action. Journal of Business Venturing, 22(1), 50-76.

De Clercq, D., \& Voronov, M. (2011). Sustainability in entrepreneurship: A tale of two logics. International Small Business Journal, 29(4), 322-344.

Dey, P., \& Mason, C. (2018). Overcoming constraints of collective imagination: An inquiry into activist entrepreneuring, disruptive truth-telling and the creation of 'possible worlds'. Journal of Business Venturing, 33(1), 84-99.

DiVito, L., \& Bohnsack, R. (2017). Entrepreneurial orientation and its effect on sustainability decision tradeoffs: The case of sustainable fashion firms. Journal of Business Venturing. 32(5), 569-587.

Dorado, S. (2006). Social entrepreneurial ventures: different values so different process of creation, no?. Journal of Developmental Entrepreneurship, 11(04), 319-343.

Edquist, C. (Ed.). (1997). Systems of innovation: technologies, institutions, and organizations. Psychology Press.

Edmondson, A.C., McManus, S.E., (2007). Methodological fit in management field research. Academy of Management Review. 32(4), 1246-1264.

Eisenhardt, K. M. (1989). Building theories from case study research. Academy of Management Review, 14(4), $532-550$.

Elkington, J. (1994). Towards the sustainable corporation: Win-win-win business strategies for sustainable development. California Management Review, 36(2), 90-100.

Etzkowitz, H., \& Klofsten, M. (2005). The innovating region: toward a theory of knowledge-based regional development. $R \& D$ Management, 35(3), 243-255.

Freeman, C. (2002). Continental, national and sub-national innovation systems-complementarity and economic growth. Research Policy, 31(2), 191-211.

Florida, R., Gulden, T., \& Mellander, C. (2008). The rise of the mega-region. Cambridge Journal of Regions, Economy and Society, 1(3), 459-476.

Gertler, M. S. (2003). Tacit knowledge and the economic geography of context, or the undefinable tacitness of being (there). Journal of Economic Geography, 3(1), 75-99.

Gioia, D. A., Corley, K. G., and Hamilton, A. L. (2013). 'Seeking qualitative rigor in inductive research: notes on the Gioia methodology'. Organizational Research Methods, 16(1), 15-31.

Glaeser, E. L., Kolko, J., \& Saiz, A. (2001). Consumer city. Journal of Economic Geography, 1(1), 27-50.

Glaeser, E. L., Ponzetto, G. A., \& Tobio, K. (2014). Cities, skills and regional change. Regional Studies, 48(1), $7-43$. 
Hahn, T., Preuss, L., Pinkse, J., \& Figge, F. (2014). Cognitive frames in corporate sustainability: Managerial sensemaking with paradoxical and business case frames. Academy of Management Review, 39(4), 463-487.

Hahn, T., Pinkse, J., Preuss, L., \& Figge, F. (2015). Tensions in corporate sustainability: Towards an integrative framework. Journal of Business Ethics, 127(2), 297-316.

Hall, J. K., Daneke, G. A., \& Lenox, M. J. (2010). Sustainable development and entrepreneurship: Past contributions and future directions. Journal of Business Venturing, 25(5), 439-448.

Hockerts, K., \& Wüstenhagen, R. (2010). Greening Goliaths versus emerging Davids-Theorizing about the role of incumbents and new entrants in sustainable entrepreneurship. Journal of Business Venturing, 25(5), 481492.

Isenberg, D. J. (2010). How to start an entrepreneurial revolution. Harvard Business Review, 88(6), 40-50.

Klag, M., \& Langley, A. (2013). Approaching the conceptual leap in qualitative research. International Journal of Management Reviews, 15(2), 149-166.

Kuratko, D. F., Fisher, G., Bloodgood, J. M., and Hornsby, J. S. (2017). The paradox of new venture legitimation within an entrepreneurial ecosystem. Small Business Economics, 1-22.

Langley, A. (1999). Strategies for Theorizing from Process Data. Academy of Management Review, 24, 691710.

Langley, A., Smallman, C., Tsoukas, H., \& van de Ven, A. (2013). Process studies of change in organization and management: unveiling temporality, activity, and flow. Academy of Management Journal, 56(1), 1-13.

Lundvall, B. Å., Johnson, B., Andersen, E. S., \& Dalum, B. (2002). National systems of production, innovation and competence building. Research Policy, 31(2), 213-231.

Mair, J., \& Marti, I. (2006). Social entrepreneurship research: A source of explanation, prediction, and delight. Journal of World Business, 41(1), 36-44.

Marsden, T., \& Smith, E. (2005). Ecological entrepreneurship: sustainable development in local communities through quality food production and local branding. Geoforum, 36(4), 440-451

Meek, W. R., Pacheco, D. F., \& York, J. G. (2010). The impact of social norms on entrepreneurial action: Evidence from the environmental entrepreneurship context. Journal of Business Venturing, 25(5), 493-509.

Muñoz, P., \& Dimov, D. (2015). The call of the whole in understanding the development of sustainable ventures. Journal of Business Venturing, 30(4), 632-654.

Muñoz, P., \& Cohen, B. (2018). Entrepreneurial Narratives in Sustainable Venturing: Beyond People, Profit, and Planet. Journal of Small Business Management, 56, 154-176.

Neck, H. M., Meyer, G. D., Cohen, B., \& Corbett, A. C. (2004). An entrepreneurial system view of new venture creation. Journal of Small Business Management, 42(2), 190-208.

Nelson, R. R. (Ed.). (1993). National innovation systems: a comparative analysis. Oxford university press.

Neumeyer, X., Santos, S. C., Caetano, A., \& Kalbfleisch, P. (2018). Entrepreneurship ecosystems and women entrepreneurs: a social capital and network approach. Small Business Economics, 1-15.

Pacheco, D. F., Dean, T. J., \& Payne, D. S. (2010). Escaping the green prison: Entrepreneurship and the creation of opportunities for sustainable development. Journal of Business Venturing, 25(5), 464-480.

Parrish, B. D. (2010). Sustainability-driven entrepreneurship: Principles of organization design. Journal of Business Venturing, 25(5), 510-523. 
Pentland, B. T. (1999). Building process theory with narrative: From description to explanation. Academy of Management Review, 24(4), 711-724.

Roundy, P. T., Brockman, B. K., \& Bradshaw, M. (2017). The resilience of entrepreneurial ecosystems. Journal of Business Venturing Insights, 8, 99-104.

Saxenian, A. (1996). Regional advantage. Harvard University Press.

Schaltegger, S. and Wagner, M., (2011). Sustainable entrepreneurship and sustainability innovation: categories and interactions. Business Strategy and the Environment. 20(4), 222-237.

Schaltegger, S. and Hansen, E.G., (2013). Industry transformation through sustainable entrepreneurship, examples in the apparel and energy industries. In: McIntosh, M. (Ed.), The Necessary Transition. The Journey Towards the Sustainable Enterprise Economy. Greenleaf Publishing, Sheffield, pp. 182-197.

Schlange, L. E. (2009). Stakeholder Identification in Sustainability Entrepreneurship. Greener Management International, (55).

Shepherd, D. A., \& Patzelt, H. (2011). The new field of sustainable entrepreneurship: Studying entrepreneurial action linking "what is to be sustained" with "what is to be developed". Entrepreneurship Theory and Practice, 35(1), 137-163.

Simatupang, T. M., Schwab, A., \& Lantu, D. C. (2015). Building sustainable entrepreneurship ecosystems, Introduction. International Journal of Entrepreneurship and Small Business, 26(4), 389-398.

Smith, A., \& Raven, R. (2012). What is protective space? Reconsidering niches in transitions to sustainability. Research Policy, 41(6), 1025-1036.

Soskice, D. W., \& Hall, P. A. (2001). Varieties of capitalism: The institutional foundations of comparative advantage. Oxford: Oxford University Press.

Spigel, B. (2015). The relational organization of entrepreneurial ecosystems. Entrepreneurship Theory and Practice, 41(1), 49-72.

Stam, E. (2014). The Dutch entrepreneurial ecosystem. Retrieved October 24, 2014 from http://papers.ssrn.com/sol3/papers.cfm?abstract_id=2473475.

Stam, E. (2015). Entrepreneurial ecosystems and regional policy: a sympathetic critique. European Planning Studies, 23(9), 1759-1769.

Szerb, L. A., Acs, Z., \& Autio, E. (2013). Entrepreneurship and policy: The national system of entrepreneurship in the European Union and in its member countries. Entrepreneurship Research Journal, 3(1), 9-34.

Watkins, A., Papaioannou, T., Mugwagwa, J., \& Kale, D. (2015). National innovation systems and the intermediary role of industry associations in building institutional capacities for innovation in developing countries: A critical review of the literature. Research Policy, 44(8), 1407-1418.

Wesseling, J. H., \& Van der Vooren, A. (2017). Lock-in of mature innovation systems: the transformation toward clean concrete in the Netherlands. Journal of Cleaner Production, 155, 114-124.

Whitley, R. (2000). The institutional structuring of innovation strategies: business systems, firm types and patterns of technical change in different market economies. Organization Studies, 21(5), 855-886.

Woolley, J. L. (2014). The creation and configuration of infrastructure for entrepreneurship in emerging domains of activity. Entrepreneurship Theory and Practice, 38(4), 721-747.

York, J. G., \& Venkataraman, S. (2010). The entrepreneur-environment nexus: Uncertainty, innovation, and allocation. Journal of Business Venturing, 25(5), 449-463.

Yin, R. K. (2003). Case Study Research: Design and Methods (Vol. 3rd Edition). London: Sage Publications. 
Zahra, S. A., \& Nambisan, S. (2011). Entrepreneurship in global innovation ecosystems. Academy of Marketing Science, 1(1), 4.

Zahra, S. A., Gedajlovic, E., Neubaum, D. O., \& Shulman, J. M. (2009). A typology of social entrepreneurs: Motives, search processes and ethical challenges. Journal of Business Venturing, 24(5), 519-532. 
Table 1. Overview of data sources

\begin{tabular}{|c|c|c|c|c|c|}
\hline Company & Location & $\begin{array}{l}\text { Number of } \\
\text { Interviews }\end{array}$ & $\begin{array}{l}\text { Position of respondent } \\
\text { (interviews) }\end{array}$ & $\begin{array}{l}\text { Observation } \\
\text { (visits) }\end{array}$ & $\begin{array}{l}\text { Supplementary } \\
\text { documentation }\end{array}$ \\
\hline $\begin{array}{l}\text { House of Denim, } \\
\text { Denim City }\end{array}$ & $\begin{array}{l}\text { Amsterdam, } \\
\text { Netherlands }\end{array}$ & 4 & $\begin{array}{l}\text { Founder (2) } \\
\text { Project Manager (2) }\end{array}$ & $\begin{array}{l}\text { Meetings (2) } \\
\text { Factory tour } \\
(2)\end{array}$ & $\begin{array}{l}\text { Web site, press } \\
\text { articles, Denim } \\
\text { Roadmap strategy }\end{array}$ \\
\hline Denim Brand & $\begin{array}{l}\text { Amsterdam, } \\
\text { Netherlands }\end{array}$ & 2 & Founder (2) & -- & $\begin{array}{l}\text { Web site, press } \\
\text { articles }\end{array}$ \\
\hline Denim Mill & $\begin{array}{l}\text { Valencia, } \\
\text { Spain }\end{array}$ & 2 & $\begin{array}{l}\text { CEO/Founder (1) } \\
\text { Project Manager (1) }\end{array}$ & $\begin{array}{l}\text { Factory tour } \\
\text { (1) }\end{array}$ & $\begin{array}{l}\text { Web site, press } \\
\text { articles, company } \\
\text { documentation }\end{array}$ \\
\hline Yarn Spinner & $\begin{array}{l}\text { Valencia, } \\
\text { Spain }\end{array}$ & 2 & $\begin{array}{l}\text { CEO/Founder (1) } \\
\text { Independent Sales } \\
\text { Agent (1) }\end{array}$ & Factor tour (1) & Web site \\
\hline Textile Collector & $\begin{array}{l}\text { Utrecht, } \\
\text { Netherlands }\end{array}$ & 1 & Project Manager (1) & -- & Web site \\
\hline
\end{tabular}

Table 2. Main geographic specializations of the denim industry

\begin{tabular}{|c|c|c|}
\hline Region & Country & Denim specialization \\
\hline North & USA & Denim brands, design, marketing \\
\hline America & Canada & \\
\hline \multirow[t]{3}{*}{ Europe } & Northern Europe & Denim brands, design, marketing \\
\hline & Spain, Italy, France & Denim fabric production (mills), yarn spinning \\
\hline & Turkey & $\begin{array}{l}\text { Denim fabric production (mills), yarn spinning, } \\
\text { laundry facilities (cut, sew, finishing) }\end{array}$ \\
\hline Asia & $\begin{array}{l}\text { Pakistan, China, India, Vietnam, } \\
\text { United Arab Emirates }\end{array}$ & $\begin{array}{l}\text { Denim fabric production (mills), yarn spinning, } \\
\text { laundry facilities (cut, sew, finishing) }\end{array}$ \\
\hline Africa & Morocco, Tunisia, Ethiopia & Laundry facilities (cut, sew, finishing) \\
\hline
\end{tabular}


Table 3. Selected quotations for the conditions of sustainable entrepreneurial ecosystems

\section{Sustainability orientation of actors \\ House of Denim, the foundation, was started with the denim industry, from the denim industry and the brands to give it a more} sustainable character and to search for more sustainable solutions. (Denim City)

... part of great products is making it in a fair way and making it with sustainable components. (Denim Brand)

... think it's more than clear ... that [sustainability] is a way to [be] different ... this is a mission that [we] have to follow. (Denim Mill)

Because we [denim industry] have still to fight ... to improve ... although we're talking about ... progress ... it's still too slow and not [concrete] things ... (Denim Mill)

\section{Recognition of sustainable opportunities and resource mobilization}

... everyone who hears about the project thinks it's terrific and wants to work with us. (Denim City)

I liked ... the idea, there's too much clothing, people throw clothing away. Grow new cotton. Why not use old cotton. ... the idea's great (Denim Brand)

It was a common vision. ... the circular economy and sustainability are ... [our] main targets, so we found each other ... (Denim Mill)

... we want of course to stay as much as possible in Amsterdam. [Denim Brand] is the most sustainable that there is in this area [Amsterdam]. (Denim City)

A few mills in Italy were also interested in this project but they don't have the facilities that the mill [in Spain] could offer. ... [Denim Mill] is really busy searching for sustainable solutions so they were really the dream partner for us. (Denim City)

[Textile Collector], the sponsor of the whole [thing] ... made sure that Denim City could start this project. (Denim City)

... they're the technicians. I don't know anything about greener fabric. I know ... what I want the end result [to be] ... we could never do that by ourselves ... [Denim Mill was] so excited about it. And [Denim City] supported it with ... [government funding] to get the denim shredded and shipped to Spain on the cost of that subsidy ... (Denim Brand)

\section{Collaborative innovation of sustainability opportunities}

[Denim Mill] tested a lot ... how much percentage [we could] get [for the PCRD 1 project]. They tested 25 percent and 30 percent, but the fabric was breaking, it wasn't strong enough. (Denim Brand)

... the process [was] complicated in the beginning ... we did the first batch of the fiber, ... the first prototype, the first yarn, started blending with raw cotton because it contains about 20 percent of recycled material to make the yarn ... To achieve the right fabric is not easy, because using weft [yarn] that is already colored, to achieve a nice shade is not easy ... [we did] trials with various tones of dyeing ... (Denim Mill)

It was impossible to do [stretch denim] with recycled [yarns] ... in the weft there's Lycra and to get that... Lycra, plus organic cotton and recycled cotton. ... the mill ... [it] was not possible to do it. (Denim Brand)

... it's more the spinning part and blending part in the experimental phase, to get that right... [Denim Brand]

... our hemp experiment hasn't really been going the way we wanted it to go ... we wanted to include Dutch hemp in our fabric and we tried ... but the quality and quantity that is available from the Netherlands isn't good enough ... (Denim City)

... [Denim mill] couldn't use [the Dutch hemp] ... So then we ordered hemp from China, that got stuck at customs. So it was really a difficult project actually. ... [Then Denim Mill] didn't do anything with it because ... [lots of] customers with a lot of demands ... These [projects] are extra things ... for us, it's normal ... other companies who do not have sustainable hearts, they won't do it ... I mean, if you have one hundred things to do a day and 20 things are nice to have and the others are essential for your business, you will do those 80 things first and then there is no time for the other 20 things ... (Denim Brand)

... hemp needs a certain humidity and certain conditions to be spun, so [that] was one of the problems. (Denim Mill)

[PCRD 2] the fabric, product was ... way nicer than [PCRD 1] ...it was more comfortable, lighter. I liked the hemp part ... really made ... a nice crispy hand feel ... the color was nicer also ... it was a really good next evolution ... (Denim Brand)

Markets for sustainable products

... we had a few customers who bought it just for the story, and in the end [PCRD] didn't sell because ... consumers wanted ... mainly stretch denim and [PCRD] was not stretch. ... the business at the moment ... is stretch denim ... it's quite a hard sell. (Denim Brand)

... the real hindrance is actually ... demand, and in [PCRD] $2 .$. the price was also disappointing, ... in the end ... because of all the effort, it became seven euros ... so also retail prices go up... it becomes less commercial to [do it]. And ... for Denim City ... they had a bit of a problem with the price and also limited resources. (Denim Brand)

They [denim mills] are the key people to drive things. And for them, the key people to drive things are the brands ... maybe the brands are waiting for suppliers to offer more stuff which makes it easier for the brands to develop it. Somebody needs to make a step ... [Denim Mill] asked us, can we sell [PCRD fabric] to other [brands], yeah, great, do it. (Denim Brand)

... [the high price] means that large brands [like C\&A, H\&M] to name a couple big players, could never buy this fabric because it is just too costly. (Denim City) 
Table 4. Conditional aspects of sustainable entrepreneurial ecosystems

\begin{tabular}{lll}
\hline Condition & Description & Relevant actors \\
\hline $\begin{array}{l}\text { Sustainability orientation of } \\
\text { actors }\end{array}$ & $\begin{array}{l}\text { Actors and organizations in the ecosystem - non- } \\
\text { governmental agencies, activists, entrepreneurs, firms - } \\
\text { that have an established orientation towards } \\
\text { sustainability, are born sustainable or have the ambition } \\
\text { to incorporate sustainability practices into their business } \\
\text { models }\end{array}$ & $\begin{array}{l}\text { Firms, } \\
\text { governments, } \\
\text { support } \\
\text { organizations, } \\
\text { consumers, } \\
\text { financers, educators }\end{array}$ \\
$\begin{array}{l}\text { Recognition of sustainability } \\
\text { opportunities and } \\
\text { mobilization of resources }\end{array}$ & $\begin{array}{l}\text { Ability to recognize opportunities that provide societal as } \\
\text { well as private benefits and to align other key actors to } \\
\text { explore and exploit the recognized opportunities }\end{array}$ & $\begin{array}{l}\text { Firms, support } \\
\text { organizations, } \\
\text { financers }\end{array}$ \\
sustainaborative innovation of & $\begin{array}{l}\text { Iterative entrepreneurial experimentation to explore or } \\
\text { exploit sustainability opportunities that have high risk } \\
\text { and uncertain outcomes due to capital expenditures for } \\
\text { technological equipment, use of materials that have } \\
\text { unproven outcomes, uncertain market acceptance }\end{array}$ & $\begin{array}{l}\text { Firms, support } \\
\text { organizations, } \\
\text { consumers }\end{array}$ \\
$\begin{array}{l}\text { Markets for sustainable } \\
\text { products }\end{array}$ & $\begin{array}{l}\text { Ability to appropriate economic benefits from } \\
\text { sustainable innovations and products from receptive } \\
\text { consumers/users in product and factor markets }\end{array}$ & Firms, consumers \\
\hline
\end{tabular}


Figure 1. Overview of concepts, themes and analytical constructs

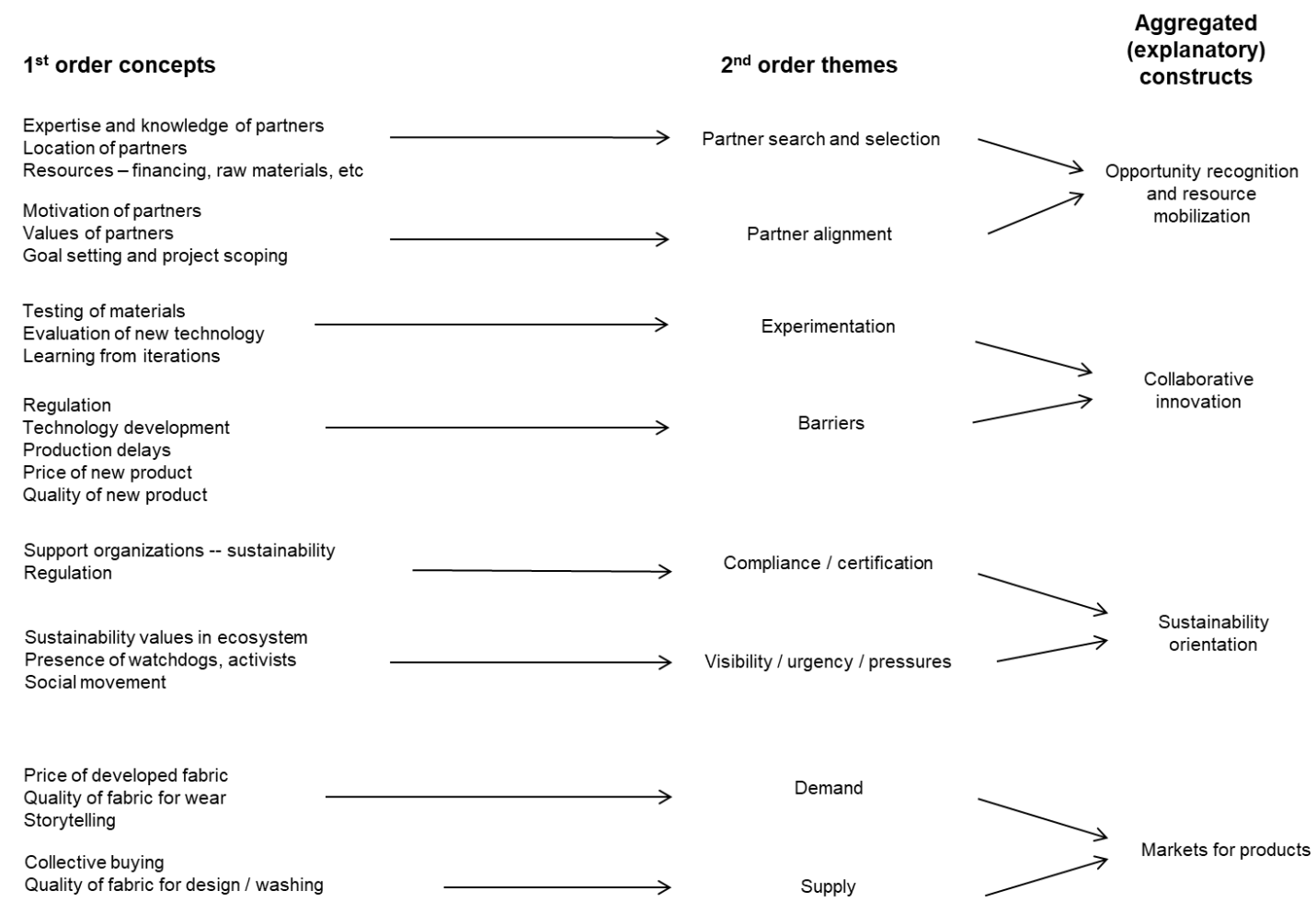


Figure 2. Entrepreneurial ecosystem of Amsterdam denim industry*

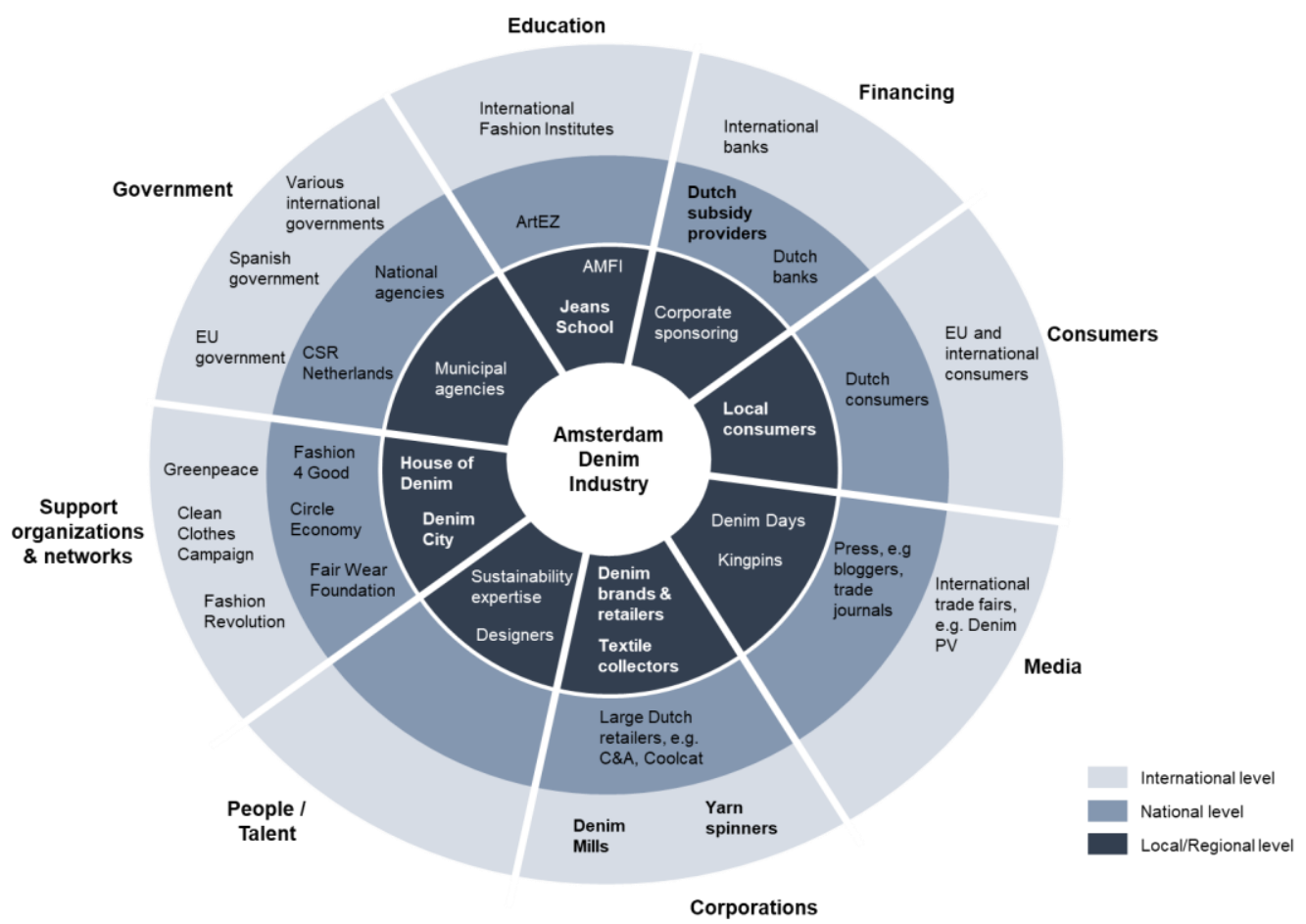

* Actors shown in the diagram are examples and do not represent the entire ecosystem. The core actors involved in the PCRD project are in bold type and include: Denim City, Denim Brand, Textile Collector, local consumers on the local level, Dutch subsidy provider on the national level and Denim Mill and Yarn Spinner on the international level.

Figure 3. Relation between the conditions and actors of sustainable entrepreneurial ecosystems, the case of the Amsterdam denim industry PCRD project

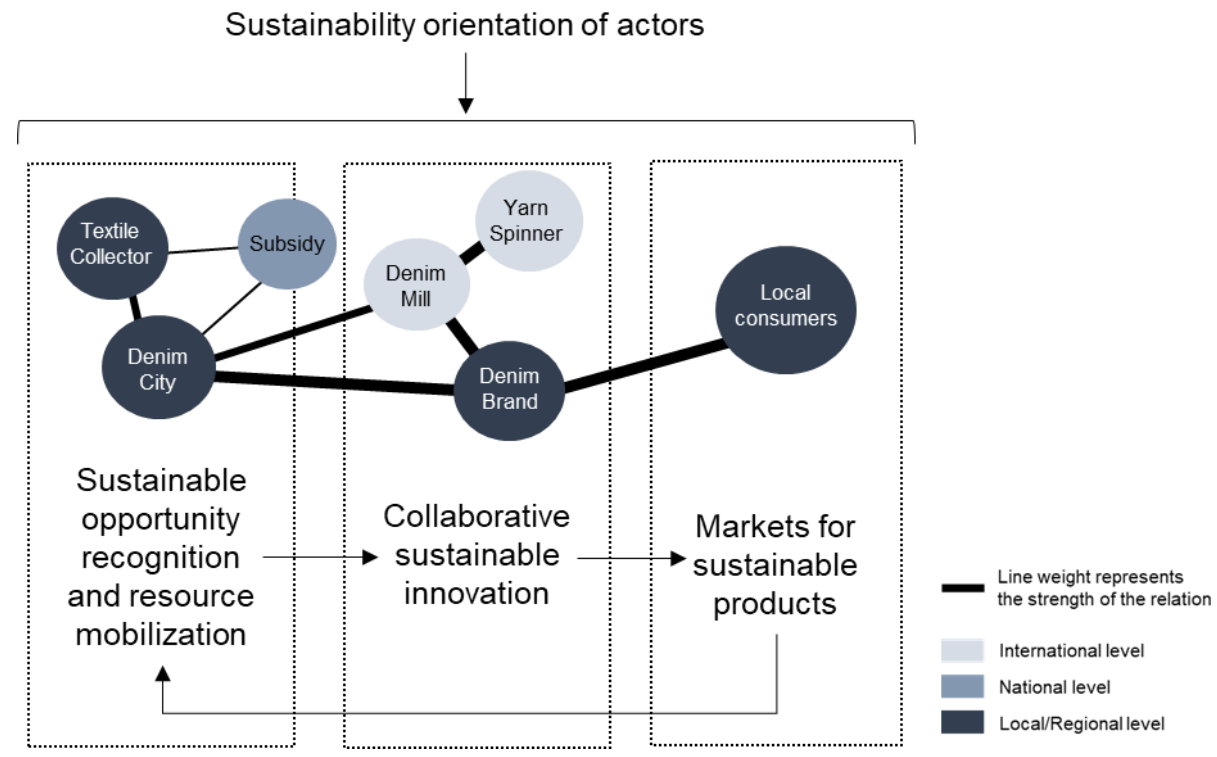

